\title{
Assess The Efficacy of Shaman Snehapana of Lekhanataila in the Management of Sthaulya W.R.T. Obesity.
}

\author{
${ }^{1}$ Kulkarni Niraj, ${ }^{2}$ More Manjusha, ${ }^{3}$ Bhoi Nehal, ${ }^{4}$ VaibhavPhartale \\ ${ }^{1,3}$ PG Scholar, Department of Panchakarma, S.S.A.M College, Nashik. \\ ${ }^{2}$ Professor/HOD, Department of Panchakarma, S.S.A.M College, Nashik. \\ ${ }^{4}$ Associate Professor, Department of Kayachikitsa, S.S.A.M. college, Nashik.
}

\begin{abstract}
:-
Sthaulya is one of the increasing disease in today's life style. Many Shodhana therapies are used in practise to treat this Vyadhi, but every patient is not ready for Shodhanatherapy and also it isper day time consuming procedure. So in present study Shamana Snehapana of Lekhana Tailais given to 10 patients,in Madyam Matra i.e.30ml for 28days.It is found that Snehapana of Lekhana Tailagives remarkable results subjectively and objectively. Though the treatment takes long duration to give result, it is economical and patient's per day time is also saved.
\end{abstract}

Keywords:Sthaulya, Vyadhi, Shodhana, Shamana, Snehapana,LekhanaTaila.

INTRODUCTION:-Ayurveda is a holistic approach of lifeand in ayurveda many kashtasadhya diseases and their treatments are described like Shodhana and shamanachikitsa ${ }^{[1]}$.

According to Ayurveda Sthaulya is described under the heading 'Ashtoninditiya'. Prevanace of Sthaulya is increasing day by day due to junk food, desk work, unhealthy lifestyle. There are many therapies available for treating sthaulya like Shodhana, Dietplan, Excercise, Yoga, oral hormonal medicines etc. In Ayurveda shodhana therapy mainly indicated in management of sthaulya but this therapy is not economical, patient have to follow so many diet regimens and takes minimum 15days.

In today's life-style patient is not easily convinced for Shodhana therapy because of time limitations. So ShamanaSnehapana of Lekhanatailawas selected in present study.

\section{AIMS AND OBJECTIVES :-}

1. To assess the efficacy of Shaman snehapana of Lekhanataila in the management of Sthaulya.

2. To study the disease Sthaulya according to modern and ayurvedicascepts.

Selection of patients:- The patients of sthaulya attending the OPD and IPD of SSAM and H of Panchakarma department were selected for study.

\section{MATERIALS AND METHODS :-}

Material :Drug used for present study was Lekhanataila which was prepared as per classical Snehapakavidhi ${ }^{[2]}$ and the contents of the taila were selected from Lekhaniyamahakashaya ${ }^{[3]}$ as per mentioned in Charakasamhita.

Quantity of contents of Lekhanataila per liter is given in chart below. 
${ }^{1}$ Kulkarni Niraj, International Journal of Ayurvedic\& Herbal Medicine 7(6) Nov.-Dec. 2017 (2942-2947)

Table no.1.Contents of Lekhana Tail.

\begin{tabular}{|c|c|c|c|}
\hline Sr.no & Drugs & Latin name & Quantity \\
\hline 1 & Musta & Cyperusrotundus & $200 \mathrm{mg}$ \\
\hline 2 & Kushtha & Saussurealappa & $200 \mathrm{mg}$ \\
\hline 3 & Haridra & Curcuma longa & $200 \mathrm{mg}$ \\
\hline 4 & Daruharidra & Berberisaristata & $200 \mathrm{mg}$ \\
\hline 5 & Vacha & Acoruscalamus & $200 \mathrm{mg}$ \\
\hline 6 & Ativisha & Aconitum heterophylum & $200 \mathrm{mg}$ \\
\hline 7 & Katuka & Picrorhizakurrao & $200 \mathrm{mg}$ \\
\hline 8 & Chitraka & Plumbegozelanica & $200 \mathrm{mg}$ \\
\hline 9 & Karanj & Holopteliaintegrifolia & $200 \mathrm{mg}$ \\
\hline 10 & Hemavati & Iris ensata & $200 \mathrm{mg}$ \\
\hline 11 & TilaTaila & Sesamumindicum & 1 liter \\
\hline
\end{tabular}

\section{Method :}

Route of Administration : Oral

Drug :-Lekhanataila.

Dose :-In MadyamMatra i.e.30ml after proper digestion of food taken during the earlier meal.

Anupana :-Ushnodaka

Duration :-28 days

Sample Size :- 10

Follow up :- On $14^{\text {th }}$ and $28^{\text {th }}$ day.

\section{Inclusion criteria}

1. The patients having clinical signs and symptoms of Sthaulya

2. The patients whose age above 15 and below 50 years were selected.

3. Standard height and weight chart was also considered

4. BMI criteria were also followed for selection of patients

\section{Exclusion criteria}

1. The patients whose age is below 15 and above 55 years.

2. Patients with Diabetes mellitus

3. Patients with long term steroid treatment.

4. Patients with hypothyroidism.

5. Patients with evidence of renal hepatic and cardiac involvement.

\section{Assessment criteria:-}

\section{Subjective parameters ${ }^{[4]}$}

1. Javoparodha (Utsahahani)

2. Kruchavayayata

3. Daurbalya

4. Daurgandhya

5. Swedabadha (Atisweda)

6. Kshudhaatimatra (Atikshudha)

7. Atipipasa

\section{Objective parameters}

1. Body Mass Index $(\mathrm{BMI})^{[5]}=$ Weight in $\mathrm{kg} \div(\text { Height in meter })^{2}$

2. Waist hip ratio $(\mathrm{WHR})^{[6]}=$ Waist $\div$ Hip 
${ }^{1}$ Kulkarni Niraj, International Journal of Ayurvedic\& Herbal Medicine 7(6) Nov.-Dec. 2017 (2942-2947) OBSERVATIONS :-

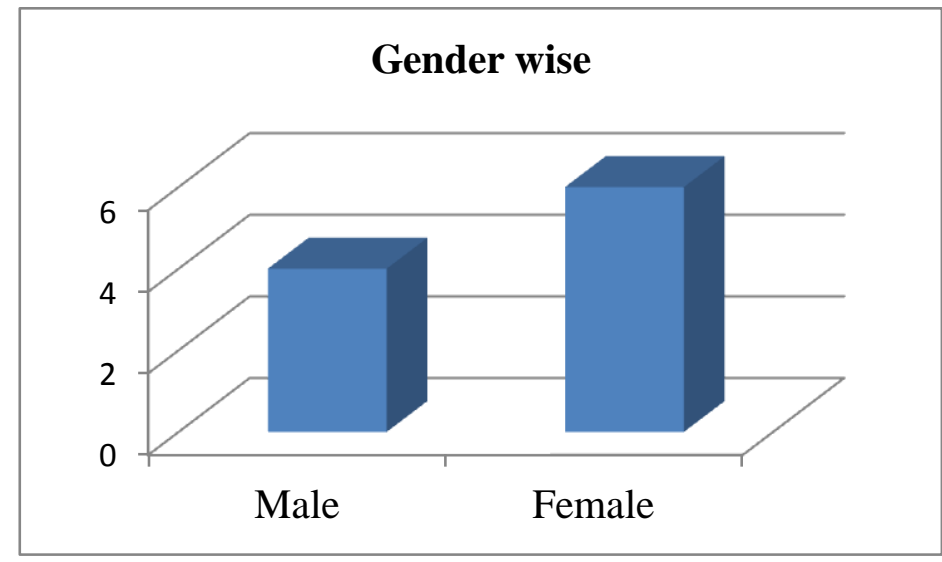

Tableno.2 Gender wise distribution of patients : Number of female patients suffering from Sthaulya was more than number of male patient probably due to lack of excercise, health negligence etc.

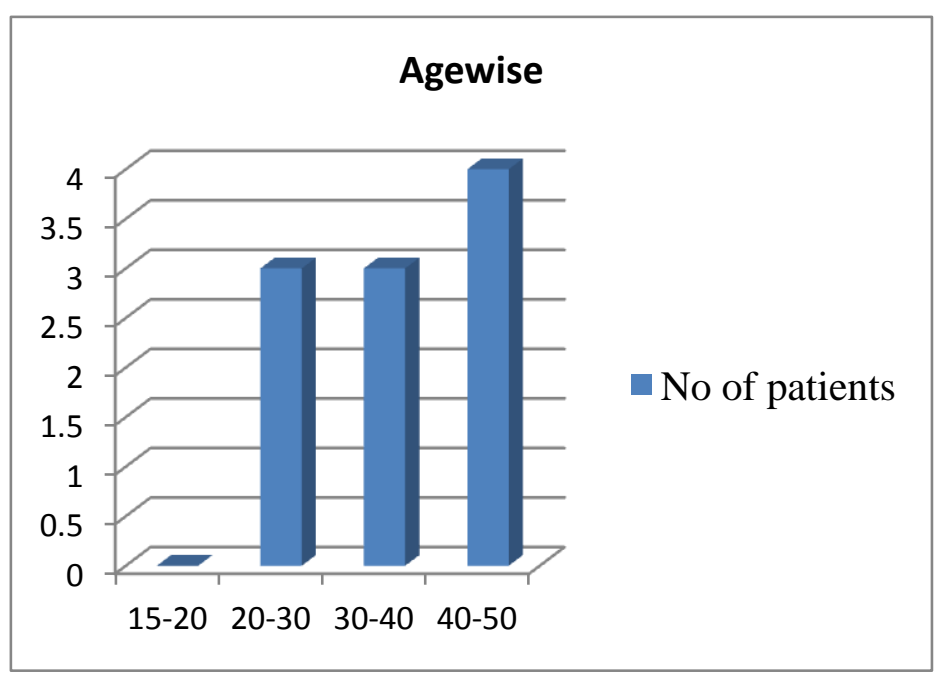

Table no. 3 Age wise distribution of patients : Patients of age group 40 to 50 years are more prone to Sthaulya than other because of Vataprakopakala.

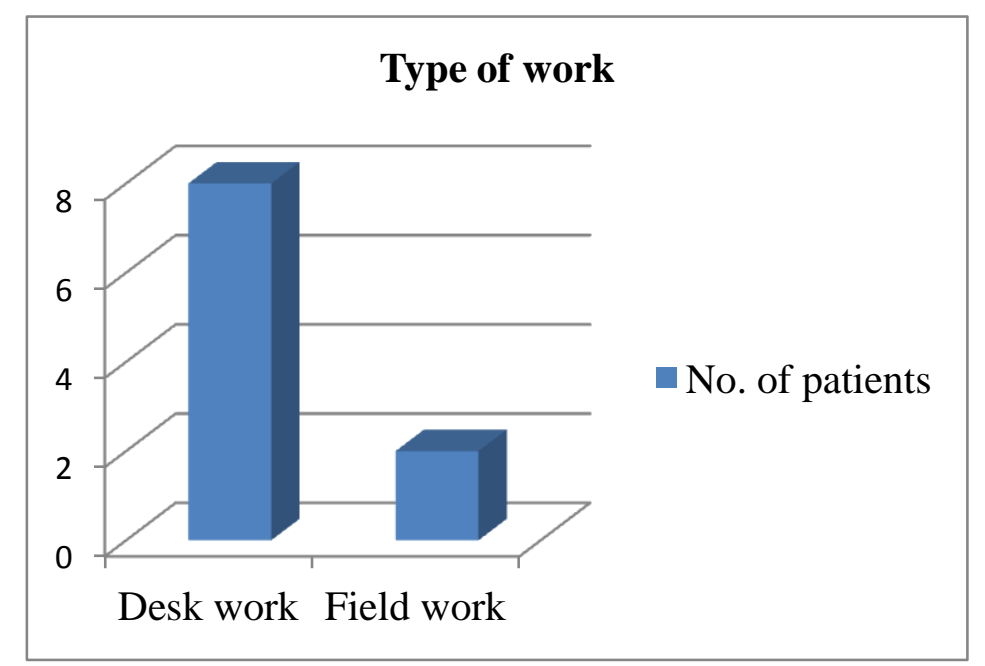

Table no. 4. Occupation wise distribution of patients:Patients doing desk work are more prone to Sthaulya.Probably because of less physical efforts. 
${ }^{1}$ Kulkarni Niraj, International Journal of Ayurvedic\& Herbal Medicine 7(6) Nov.-Dec. 2017 (2942-2947)

Table no.5. Observations found in Subjective parameters

Before Treatment(BT) and After Treatment(AT)

\begin{tabular}{|c|c|c|c|c|c|c|c|c|c|c|c|c|c|c|}
\hline \multirow[t]{2}{*}{ No } & \multicolumn{2}{|c|}{ Javoparodha } & \multicolumn{2}{|c|}{$\begin{array}{c}\text { Karuchchh } \\
\text { vyavayata }\end{array}$} & \multicolumn{2}{|c|}{ Daurbalya } & \multicolumn{2}{|c|}{$\begin{array}{c}\text { Daur- } \\
\text { gandhya }\end{array}$} & \multicolumn{2}{|c|}{$\begin{array}{l}\text { Sweda } \\
\text { badha }\end{array}$} & \multicolumn{2}{|c|}{$\begin{array}{l}\text { Kshudha } \\
\text { atimatra }\end{array}$} & \multicolumn{2}{|c|}{$\begin{array}{c}\text { Ati } \\
\text { pipasa }\end{array}$} \\
\hline & BT & AT & BT & AT & BT & $\mathbf{A T}$ & BT & AT & BT & AT & BT & AT & BT & AT \\
\hline 1 & 2 & 0 & 2 & 1 & 2 & 0 & 1 & 0 & 2 & 0 & 3 & 1 & 2 & 0 \\
\hline 2 & 3 & 1 & 2 & 1 & 2 & 0 & 2 & 1 & 3 & 2 & 3 & 1 & 2 & 1 \\
\hline 3 & 2 & 1 & 2 & 0 & 1 & 0 & 2 & 0 & 2 & 0 & 2 & 1 & 1 & 0 \\
\hline 4 & 2 & 0 & 3 & 1 & 2 & 0 & 1 & 0 & 2 & 1 & 2 & 0 & 1 & 1 \\
\hline 5 & 2 & 0 & 2 & 1 & 2 & 1 & 2 & 0 & 2 & 1 & 2 & 0 & 1 & 0 \\
\hline 6 & 2 & 1 & 1 & 0 & 2 & 0 & 1 & 0 & 2 & 1 & 2 & 1 & 2 & 0 \\
\hline 7 & 1 & 0 & 3 & 1 & 3 & 1 & 2 & 1 & 2 & 1 & 3 & 1 & 3 & 2 \\
\hline 8 & 2 & 1 & 3 & 1 & 2 & 0 & 2 & 0 & 2 & 0 & 2 & 1 & 2 & 0 \\
\hline 9 & 2 & 1 & 1 & 0 & 2 & 0 & 1 & 0 & 2 & 1 & 3 & 1 & 2 & 0 \\
\hline 10 & 2 & 1 & 2 & 0 & 2 & 1 & 1 & 1 & 3 & 1 & 2 & 1 & 2 & 1 \\
\hline$\sigma x$ & 2 & 0.6 & 2.1 & 0.6 & 2 & 0.3 & 1.5 & 0.3 & 2.2 & 0.8 & 2.4 & 0.8 & 1.8 & 0.5 \\
\hline
\end{tabular}

Table no.6. Observations found in Body Mass Index and Waist Hip Ratio

\begin{tabular}{|c|c|c|c|c|}
\hline \multirow{2}{*}{ Sr. No } & \multicolumn{2}{|c|}{ Body Mass Index $\left(\mathbf{k g} / \mathbf{m}^{\mathbf{2}}\right.$} & \multicolumn{2}{c|}{ Waist Hip Ratio } \\
\cline { 2 - 5 } & B T & AT & B T & AT \\
\hline 1 & 30.22 & 29.33 & 1.04 & 0.98 \\
\hline 2 & 40.77 & 40.07 & 0.93 & 0.9 \\
\hline 3 & 33.3 & 32.39 & 0.89 & 0.86 \\
\hline 4 & 33.33 & 32.05 & 0.92 & 0.88 \\
\hline 5 & 28.14 & 27.31 & 0.94 & 0.9 \\
\hline 6 & 27.4 & 26.16 & 0.9 & 0.86 \\
\hline 7 & 29.49 & 28.64 & 0.95 & 0.92 \\
\hline 8 & 30.37 & 29.53 & 0.95 & 0.92 \\
\hline 9 & 28.1 & 27.28 & 0.94 & 0.9 \\
\hline 10 & 28.3 & 27.35 & 0.9 & 0.86 \\
\hline
\end{tabular}

\section{RESULTS:-}

Table no.7. Percentage of relief in Subjective parameters.

\begin{tabular}{|l|c|c|c|c|c|}
\hline No. & Subjective Parameters & BT & AT & X & Percentage of relief. \\
\hline 1 & Javoparodha(Utsahahani) & 2 & 0.6 & 1.4 & 70 \\
\hline 2 & Kruchavayayata & 2.1 & 0.6 & 1.5 & 71.42 \\
\hline 3 & Daurbalya & 2 & 0.3 & 1.7 & 85 \\
\hline 4 & Daurgandhya & 1.5 & 0.3 & 1.2 & 80 \\
\hline 5 & Swedabadha (Atisweda) & 2.2 & 0.8 & 1.4 & 63 \\
\hline 6 & Kshudhaatimatra & 2.4 & 0.8 & 1.6 & 66.66 \\
\hline 7 & Atipipasa & 1.8 & 0.5 & 1.3 & 72.22 \\
\hline
\end{tabular}


${ }^{1}$ Kulkarni Niraj, International Journal of Ayurvedic\& Herbal Medicine 7(6) Nov.-Dec. 2017 (2942-2947)

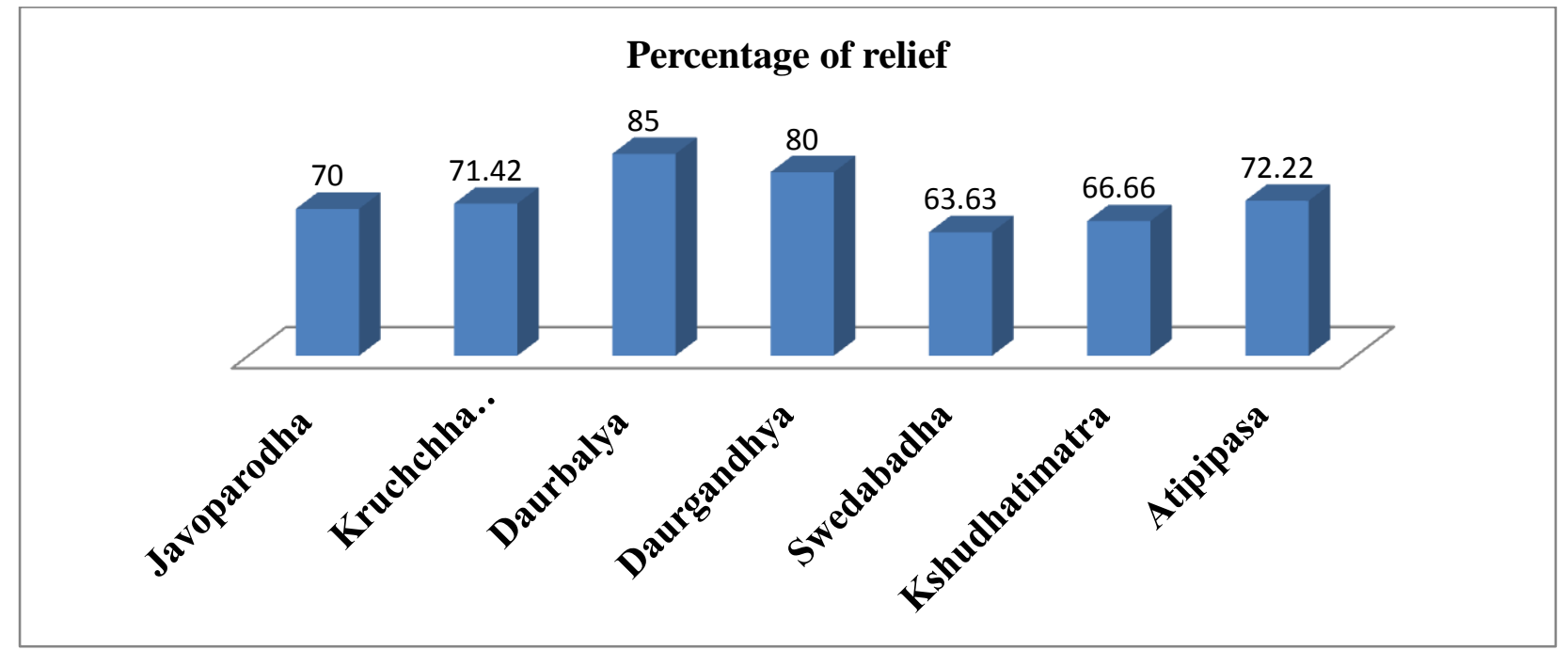

Table no.8. Patient wise Weight Loss in Kilograms.

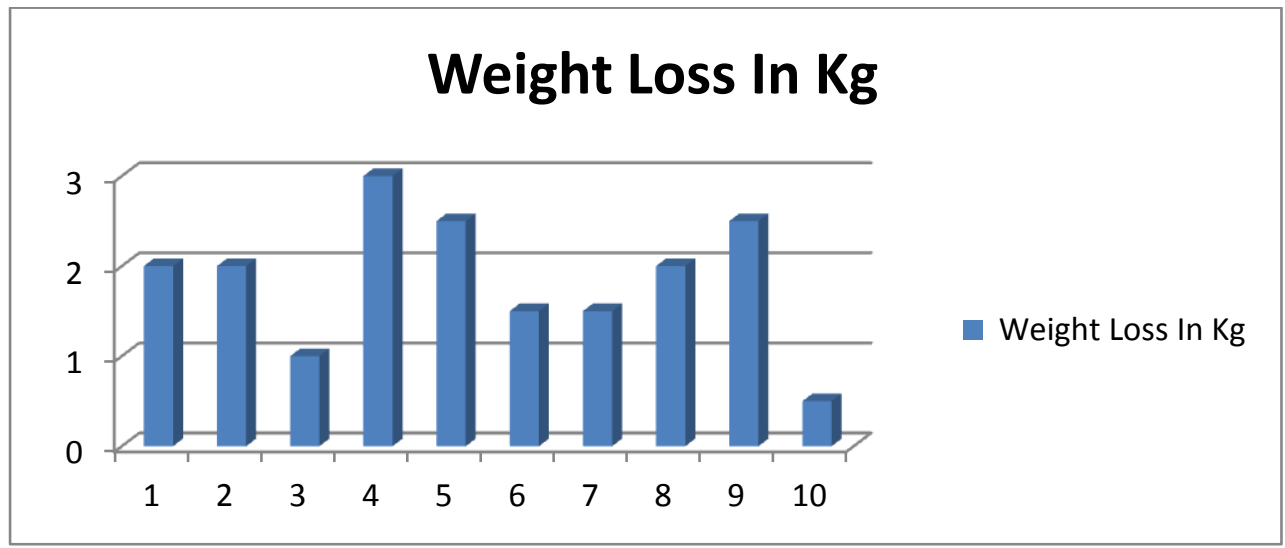

\section{DISCUSSION:-}

Abhyantara Snehapan is divided according to their Karma as

1.ShodhanSnehapan 2.Shaman Snehapan .3.Bruhan Snehapan

Shaman Snehapan -In this type of Snehapana when Sneha is administered with an intention to normalize the aggreavateddos has without expelling them out. It has been explained by Hemadri that if Shaman Sneha is administered after the digestion of previous diet(Jirnaahare,)vitiated doshas doesn't expels out of sharir but the Sneha pacifies the doshas.

Shodhan and Shaman karma depends on the Matra,Kala,Anupan of the given Sneha.

Table.9. The difference between Shamanasnehapana and Shodhansnehapana

\begin{tabular}{|c|c|}
\hline Shamanasnehapana & Shodhanasnehapana \\
\hline $\begin{array}{l}\text { Merits } \\
\text { - Less time consuming per day } \\
\text { - Economical } \\
\text { - Less number of drugs are } \\
\text { Required in less quantity } \\
\text { - No need of Paricharaka } \\
\text { - No need of Panchakarma setup } \\
\text { - No strict diet regimens }\end{array}$ & $\begin{array}{l}\text { Merits } \\
\text { - Mulachchhedana } \\
\text { - Total duration of therapy is less. } \\
\text { - More effective }\end{array}$ \\
\hline
\end{tabular}


${ }^{1}$ Kulkarni Niraj, International Journal of Ayurvedic\& Herbal Medicine 7(6) Nov.-Dec. 2017 (2942-2947)

\begin{tabular}{|l|l|}
\hline Demerits & Demerits \\
- Punarudhbhava is possible. & - More time consuming per day \\
- Total duration of therapy is more & - Costly \\
& - More number of drugs \\
& - Required in more quantity \\
& - Many Paricharakas needed \\
& - Panchakarma setup needed \\
& - Strict diet regimens. \\
\hline
\end{tabular}

Thus as above comparison we can say that except demerits of Punarudhbhava, Shaman Snehapan proves to be beneficial. Especially we can advise it,when the given patient is contraindicated for the Shodhan therapy.

\section{Probable Mode of action of LekhantailaSnehapan}

Contents of the Lekhanataila were selected from LekhaniyaMahakashaya. So they were Lekhan in gunasi.e.they scrap the Medadhatu.Also most of them were tikshna,ushna,ruksha and also vataghna in nature.

In Sthaulyasampraptivataprakopa ,medadushti and dhatvagnimandya are main causative factors ${ }^{[7]}$ and Lekhanataila causes kapha,vata,medaghna effect.

Thus by administering Lekhantaila in Shaman module,Sthaulyasampraptibhanga may be done by by controlling the vata,reducing the kapha-meda and correcting dhatvagnimandya

\section{CONCLUSION :-}

$\checkmark$ Shaman Snehapan may be the Treatment of choice when the patient is contraindicated for ShodhanChikitsa.

$\checkmark$ Shamanasnehapana of Lekhanataila was found effective inSthoulya subjectively and objectively.

\section{REFERENCES :-}

1. Shashtrikashinath and Chaturvedi Gorakhnath; Charaksamhita of Agnivesha with Vidyotani Hindi commentary, Sutrasthan 22/4, Chaukhambhasanskritbsansthan, Varanasi,1992,p 309.

2. Tripathi Bramhananda : Sharangdhar Samhita with Dipika Hindi commentary, Reprinted in 2008, Chauhamba SubhartiPrakashana, Varanasi, Madyamkhanda 9/6,7.

3. Shashtrikashinath and Chaturvedi Gorakhnath; Charaksamhita of Agnivesha with Vidyotani Hindi commentary, Sutrasthan 4/2, Chaukhambhasanskritbsansthan, Varanasi,1992,p 148.

4. Shashtrikashinath and Chaturvedi Gorakhnath; Charaksamhita of Agnivesha with Vidyotani Hindi commentary, Sutrasthan 21/4, Chaukhambhasanskritbsansthan, Varanasi,1992,p 301

5. Understanding your healthy weight: Body Mass Index(BMI) and Waist Hip Ratio (WHR), www.nhsinform.scot

6. Understanding your healthy weight: Body Mass Index(BMI) and Waist Hip Ratio (WHR), www.nhsinform.scot

7. Shashtri Ambikadutta, Susruta Samhita with Ayurved Tattvasandipika, Chaukhamba Sansrit Prakashana, Varanasi, 2012, sutrasthana 24/13, p 132. 